\title{
Exploration of the Windfall and Market Entrepreneurship During the Great Recession
}

\author{
Amaechi N. Nwaokoro ${ }^{1}$, Lee Washington ${ }^{1}$ \& Autumn Griffin ${ }^{1}$ \\ ${ }^{1}$ College of Business, Albany State University, Albany, USA \\ Correspondence: Amaechi N. Nwaokoro, College of Business, Albany State University, 504 College Drive, Albany, \\ Georgia 31705, USA. Tel: 229-430-4723.
}

Received: December 8, 2018

Accepted: May 23, 2019

Online Published: August 8, 2019

doi:10.5430/ijfr.v10n6p15

URL: https://doi.org/10.5430/ijfr.v10n6p15

\begin{abstract}
Market innovative entrepreneurs have the desire of exploring declining economic markets to seek for windfall. They seek to profit heavily from adverse market conditions. The Great Recession may have presented some economic disasters, rage, and hardship to many people in the housing market in the 2000s but to the innovative market entrepreneurs, it presented some economic opportunities for experiencing a market windfall. Mostly, the objective of this exploratory study is to highlight the impact of the opportunistic events created by the housing foreclosure fillings, completed foreclosures, and home repossessions on the indexed price of housing that harbors the related opportunity cost. The increased indexed price of the housing driven by the fluctuation of both the quantity demanded and produced of housing seems to have led to the entrepreneurial windfall profit during the recession.
\end{abstract}

Keywords: entrepreneurship, windfall, arbitrage, entrepreneurial-speculation, foreclosures-fillings, foreclosures-completed, homes-repossessed, conspicuous-consumption, overconsumption, American dreams, market failure, asymmetric information

\section{Introduction}

The Great Recession may have presented some adverse market conditions but to the innovative housing market entrepreneurs, it may have presented some economic opportunities for experiencing a market splendid windfall. From the perceived speculative advantages especially in a declined market such as the housing market, the entrepreneurs have the desires to maximize economic profits with arbitrage--buying at low prices and selling at high prices in the resale markets. Specifically, an entrepreneurial market speculation involves the movement of goods from the abundant times or places to those of scarcity.

Speculative buying and selling engagement tends to even out output/price variation (risk). Particularly, the entrepreneurs would wish to purchase their goods from the declining competitive markets to resell in concentrated markets to command imperfectly competitive prices and profit. Entrepreneurs would visit declining markets looking for deals. Particularly, they may have ventured into the real estate market that plummeted in the 2000 s due to the declining growth rate of the average incomes. The reasonable growth rate of the 1990s average income and the subprime mortgage rates offered for the housing industry led to the acquisition of large homes on mortgages (conspicuous consumption).

Recognizing that resources are scarce, the pivoting desires of the entrepreneurs are buying goods at very low prices and distributing them at very high prices. They would also differentiate their goods by some special market attributes to vary the prices. Even if the entrepreneurs' goods are comparable, factors such as product locations and accessibility could cause the prices of the identical goods to vary. To maximize their payoff, the entrepreneurs would keep on buying and selling until the proceeds of the last unit sold contributes the same amount to revenue as it does to cost.

Mostly, the objective of this exploratory study is to highlight the housing market windfall that is driven by the events of the foreclosure fillings, foreclosures completed, and homes repossessed in the depressed housing market during the great recessionary period of 2003 to 2014. The rest of the study is laid out as follows. Section two is devoted to reviewing the literature that reflect the events leading to the housing market crisis and section three addresses the characteristics of the modern entrepreneurs seeking for windfall. Section four highlights the importance of home ownership and certain crucial issues in the housing market and section five explains the determination of the price of 
housing that led to the entrepreneurial windfall. Section six explores the bonds market for the determination of the interest rate that could enhance some entrepreneurial comparative advantages and profit. Data, methodology, and results are handled in section seven and section eight provides the conclusion and the direction for the future study.

\section{Review of Literature: Pursuance of Profit, Utility Gratification, and Crisis in the Housing Market}

Humans are materialistically insatiable. By being insatiable, the human would never have enough of material goods. Material goods are sources of utility. The materialistic humans will therefore, apply to economic opportunities that present materialistic gains (payoffs) that would increase their utility levels (indifference curves). Economic opportunities seemed to have been explored and pursued by the entrepreneurs during the Great Recession. Particularly, the entrepreneurs (risk takers) may have profited from the massive housing foreclosures during the period. Entrepreneurs aspire to purchase and to repurchase the profitable quantities at the lowest cost and to sell them at the highest possible prices. Some people's misery would lead to opportunities for some other persons to profit from, for elevating their utility levels. With the profit earning "making money" behavior, the entrepreneurs search for the everyday profit. They aspire to earn the most profit from the randomized distributed opportunities in the conditions of either boom or bust in the different structured markets.

For those with the market foresight, venturing into a depressed market could present an opportunity for enhancing profit that may be difficult to galvanize from non-depressed competitive markets. Therefore, the market innovative entrepreneurs have the desire to profit from all markets including those in which the other market participants are sustaining losses. The market entrepreneurial buyers could lengthen the period of the existing market failure and misery by withholding purchases and repurchases to further enhance their market comparative and speculative advantages. By so doing, they will not have any regard to the desires of those that want to minimize their losses. The searchers for profits would explore and exploit any opportunity until the profit is maximized.

Several factors could account for the housing market melt-down. Specifically, the melt-down stemmed from the declined growth rate of the average income in the 2000s from the bubbled income growth of the 1990s. Between 1991 and 2000 the national average wage index increased by $4.35 \%$ whereas it increased by $2.72 \%$ in the years between 2002 and 2011, and between 2002 and 2015, the increase is by 2.76\% (Note 1). In the 1990s the impact of the Information Technology provided a boost on the growth of the average income. Without a regard as to whether or not the growth of the average income would perpetuate, some people acquired very high substantial real estates' mortgages at subprime rates.

Encouragement policies on economic development and homeownership led the financial institutions to exogenously expand the mortgage lending by right shifting the supply of the mortgage loans and the housing consumers acquired risky mortgages (Scopelliti 2014, Ellen et al. 2012). As a result of the supply shift, the quantity produced exceeded the quantity demanded of the mortgage loans and the mortgage rates eventually fell. By the beginning of the year 2000, the technology-induced average income growth started to decline and led to the inabilities for continued payments on the conspicuous consumption and overconsumption of the housing whose market plummeted as from 2006. As a consequence, the economy collapsed in around 2007 and the housing foreclosure fillings, completed foreclosures, and home repossessions became prevalent. About 30\% decline in the home prices led to the enactments of the Economic Stimulus Act of 2008 and the American Recovery and Reinvestment Act of 2009 (Rich 2013) (Note 2). This situation seemed to have created a windfall for the entrepreneurs that acquired the foreclosed homes for resale. The sale of the repurchased estates may have reasonably favored the entrepreneurs as the price of the housing and the economy later improved. As in any other markets, the entrepreneurs will engage the marginal analysis procedure to maximize the profit in the depressed housing market.

Housing foreclosing disturbance may have led the housing entrepreneurs to refinance the properties or to acquire inventories from the foreclosed and repossessed houses for resale at some favorable terms. The market distortions caused by the foreclosing and repossessing of houses had the propensity to decrease the quantity produced of housing that in turn had the propensity to increase the equilibrium indexed price of the housing. All the opportunity costs of the housing are reflected in the increased indexed price of the housing and the magnitude of the windfall is reflected by the magnitude of the positive change in the indexed price of the housing.

\section{The General Characteristics of Modern Entrepreneurs}

Entrepreneurship is foresighted, skillful, and pragmatic approach that engages the market innovative activities to maximize something of value or to minimize the cost of something of value. Schumpeter (1989) being fascinated by the innovativeness of the U.S. entrepreneurs that brought about the American revolutionary economic development in the nineteen century described the entrepreneurs as innovative searchers of profits who in the process of searching 
for the profits increased their incomes and those of others. Entrepreneurs remain as indispensable market creative risk takers in the contemporary economy and their functions have updated the neoclassical production function to the Schumpeterian production function. They engage market innovative activities with their intuition, education, and foresight and thus are able to assign the respective weighted probabilities to the occurrences of the events of success and failure. They are most likely to commence innovative activities whose probabilities of success substantially exceed the probabilities of failure.

Entrepreneurs aspire to earn the most profit from the chosen economic activities and; therefore, may not even shy away from commencing the economic activities that are expected to lead to only break-even outcomes. Particularly, they aspire to understand the concentration of firms in any particular market which is imperative for understanding the price charged, cost structures, and the expected profit from the economic activities they desire to explore. One may not have a lot of education to achieve an entrepreneurial spirit for accomplishing entrepreneurial innovative activities. Entrepreneurship is acquired generally or from some special inborn endowment (Ucbasaran, Westhead, and Wright 2007). Generally endowed entrepreneurship is mostly acquired from education, on the job experience, learning by doing, workshops, and market experience (Arrow 1985, Ashenfelter 1978). A particular functional education and an elevated passion in a particular discipline could provide the detailed knowledge and experience needed for the development of a general market entrepreneurship.

A general entrepreneurship would tend to become more significant as more contemporary functional knowledge is added to the existing knowledge (Rosenzweig 1990). The existing knowledge could be updated by engaging a functional research relative to the possessed education (Hotchkiss 1993). Traveling to and learning from some other places that promote the related entrepreneurial functional education could assist to elevate the existing knowledge. Learning by doing has the propensity to interact with the functional education to have the impact of elevating the functional efficiency in the functionally engaged activity. Learning by doing the engaged economic activity has the inclination to lead to an upward-sloping learning curve. This kind of curve would imply an increasing efficiency in the respective activity. This articulated reasoning would most likely lead the associated net benefit from the activity to exceed zero.

Inborn entrepreneurship relates to the saying that: "geniuses are born and not made" (Ucbasaran, Westhead, and Wright 2007). This specially endowed entrepreneurship is the rare type that emanates mostly from a naturally endowed talents bestowed on a very few people. It could be genetically inherited and could run in some families. This entrepreneurship that evolves from within would likely not fade in the temporary period and thus would most likely observe a greater longevity than does the functional entrepreneurship that is explained by external factors like education. An interaction between this rare entrepreneurship and the general entrepreneurship that is driven by the external factors could foster a high dimensional level of market entrepreneurship. Particularly, a functional market education would most likely elevate the inborn entrepreneurship and the individuals with these traits could be globally recognized geniuses.

Parents, and primary and secondary educational institutions have the responsibility to identify the inborn entrepreneurship for nursing and protection. These assistances could mobilize an early evolutionary development of this specially endowed entrepreneurship that could be supported with the appropriate functional education and with some enabling factors. Individuals harboring the inborn entrepreneurship are most likely to bring about some critically new inventions and establishments that would increase their incomes and those of others. With the mix of the entrepreneurship types, the housing market entrepreneurs may have engaged the critical market arbitrage during the great recessionary period to bring about the market recovery and stability, and the restoration of the consumer market confidence and utility. Unfortunately, the major issue of this rare type of the entrepreneurship is that it may not be survived upon the death of the individuals that harbor this critical entrepreneurship.

Entrepreneurship creates efficiency. Efficiency eliminates waste in the use of the scarce resources that would tend to diminish the associated cost of the respective activity. Thus, efficiency enhances the probability of achieving success and of being profitable. Being profitable by being efficient may lead to the respective patrons' affordability of the output of the entrepreneurially engaged activity. Summarily, an entrepreneurial efficiency would lead to: increased profitability, an affordability of the output of the respective activity, and elevated incomes of other people in some other activities. The other functional activities that get their economic production inputs from the efficiency-based activities may have the opportunity to enhance their own efficiency, to minimize their costs, to provide affordable output, and to maximize their profit. 


\section{The Importance of Home Ownership and the Characteristics of the Housing Market}

Some critical factors including the desire to fulfill American dreams could impact the demand for some goods including the consumption of large houses on mortgages at especially subprime rates (Scopelliti 2014). Most Americans could be said to be searching for their American dreams that would enable them to apply to higher levels of consumption. The dreams of acquiring heavy consumption could be fulfilled by the presence of subprime rates, of having opportunity to be economically productive, of being politically strong, and of being lucky. Any of these events could translate to an upward-sloping trend of the future income for the particular individual needing to fulfill an American dream to have it fulfilled.

Given economic opportunities and the desire to have dreams fulfilled, some people could have the tendency to exercise overconsumption of some particular goods that characterize these people at some particular categories. Specifically, the two events that would showcase the realized or fulfilled American dreams are comfortable large homes and expensive automobiles. Some people may even explain the comfortability of homes based on their locations and on the ethnic composition of the neighborhoods. Most Americans would agree that the consumption of both homes and automobiles as normal and durable goods are among the upper critical events in their categories of Abraham Maslow's hierarchy of needs.

The values of both homes and automobiles in an individual's consumptions could tend to describe the magnitude of the fulfilled American dreams. In other words, the presence of these two goods could explain the extent of conspicuous consumption that could be assumed to provide a sizable portion of a household's utility. Therefore, the higher the dimension of the consumption of these normal goods, the higher would be the indifference curves that describe the household's utility levels. Particularly, home ownership would tend to express some marks of successful careers, of evidence of good living, and of keeping up with the "Jones". Also, a home ownership could in turn imply a high income that could explain other consumptions at their prevailing prices or at the subprime rates. The desires to live at affluent neighborhoods and to keep up with the "Jones" could warrant some people to unnecessarily acquire oversized sub-primed home-mortgages. These blatant desires could compel some other desires to have multiple ownerships of real estates at their prevailing subprime rates to signal some higher levels of the fulfilled American dreams or of enhanced conspicuous consumptions.

Various sources could explain the failure in the housing market. Market failure could be extensive without the intervention of the opportunistic entrepreneurial agents that could lead to a market correction. To the insightful entrepreneurs that are knowledgeable about the expected behavior of some particular markets, a market failure as in the housing market could create some speculative advantages for volume purchases of houses whose prices have substantially declined. Insightful market-entrepreneurs could even create scarcity of housing in a declined housing market by engaging market arbitrage. Arbitrage involves transferring goods from the periods of plenty to the periods of scarcity to enhance windfall situations. This market conceptual attribute requires quantity purchases at the currently low prices to be transferred to the periods of booms or to the period of an increased scarcity of the goods to command higher prices and profitable opportunities.

Incomes, as a major determinant of the housing conspicuous consumption relates to the development of affluent middle- and lower- class neighborhoods. This determinant recognizes multiple-supply of housing conditions in these different neighborhoods whose associated prices are stated with respect to their costs of production. Without regard to a budget constraint, a desire to showcase or to show-off consumption may have led to a self-selection to apply to a housing market whose production condition depicts the prices that could be substantially above what some particular incomes could sustain.

An impact of asymmetric information on the side of the lending institutions seemed to have led to the twin problems of adverse selection and moral hazard in the financial and housing markets. These twin problems could affect the purchases of housing. The inability of identifying and sorting out those with good credits from those with bad credits tends to lead to the problem of adverse selection of those with less than the required credits as candidates for the large housing mortgage loans. Those with the latent or hidden bad credits and have the desire to consume without due regard to their income constraints could be described basically as consumption-oriented. Moral hazard arises whereby the immoral activities of the borrowers would lead to the nonpayment of the mortgage loans. A widespread of these market distortions--adverse selection and moral hazard could lead to market panics and uncertainty that would lead to a market failure.

Market entrepreneurs could cause a market failure particularly in a bubbling housing market and could wind up being rewarded after restoring it to a viable level. These entrepreneurs could, for example, use "white flight" to cause a market failure and then profit from the market. White flight takes place when a real estate agency sells a home to say, a 
member of a minority group in a predominantly white neighborhood. The presence of this person in this neighborhood would be expected to adversely affect the neighborhood's expected property values and utility. As a result, the white would relocate from the neighborhood. With the organized market failure, the entrepreneurs of the real estate agency would purchase the white's abandoned properties for resale and may settle the minority member to move out of the neighborhood to encourage the white to move in at higher property prices.

\section{Determining the Price of Housing That Led to the Entrepreneurial Windfall}

The housing firm could be described in the context of an oligopolistic or a monopolistic competitive market where the associated price at the equilibrium would change due to a change of the demand or of the cost of the production of housing. With a change of the state of the demand, the price of the housing would change to reflect the change of the associated cost of the expected increase or decrease of the quantity demanded. Also, the price would change to reflect the change of the cost for varying the production due to change in the inputs' prices. During the recession, the foreclosure fillings, completed foreclosures, homes repossessed, and the relatively stable interest rate seemed to have impacted both the demand and the cost of housing production.

As the recession commenced and spread, the foreclosure fillings seemed to have depressed the demand for the housing and at its prevailing price, the quantity produced seemed to have surpassed the quantity demanded of housing. Given the surplus housing, the price of the housing was depressed to clear the market of the surplus. Even in the presence of a relatively low interest rate, the depressed price of the housing seemed unable to clear the surplus housing. Therefore, the production of housing seemed to have been reduced and as the economy and the housing market improved in the non-inflationary period, the price of the housing improved for the realization of the windfall.

Throughout the recessionary period, the interest rate was relatively stable and close to zero. Given the status of the interest rate, it could therefore be argued that the increasing price of the housing, as the economy improved, was not reflecting an inflationary pressure emanating from an expansionary money supply. Both market improvement and decreasing production of housing, therefore, would stand to explain the improvement on the price of the housing. Also, since an inflationary pressure was not in place even when the economy was on the recovery path, one could argue that the cost of housing production was not a deterministic factor for explaining the gradual increasing price of the housing.

Availability of apartment complexes as substitutes for homes would seem to have delayed the market clearing of the surplus housing. With the 2000s declining rate of the average income, insecurity of employment, and people's intentions to move to some other places might have led the housing consumers to self-select the apartment housing. Particularly, the housing consumers that foreclosed their houses might have self-selected the apartment housing to recoup financially before repurchasing homes. In a nutshell, the housing market is bouncing back out of the recession. Critically, the event of home foreclosing depressed the housing market. Adjusting the production of the housing due to the foreclosures and given a relatively low interest rate, the price of the housing observed a gradual upward trend as the economy and housing market improved. Increasing price of the housing during the non-inflationary period would enable the entrepreneurs to realize some windfall.

\section{Exploring the Bonds Market for the Determination of Interest Rate}

The economic market for bonds is explored here to highlight how the innovative entrepreneurs achieve their speculative advantages and windfall profit expectations given the interest rate. Interest rate is crucial to entrepreneurs as it explains the cost of borrowing money. Also, recall that given resource constraints that the objectives of the risk takers are to earn the most profit with among other crucial factors, borrowing at the lowest interest rate. Most people may not perceive the bonds market as being an economic market. The importance of this market has to be understood as being the arena where an interest rate that governs other interest rates is set. Entrepreneurs tend to understand this market for the formation of investments. People could retire from their functionalities in the labor and product markets and may leave their saved money in the bonds market to actively earn money by the amount of the contracted interest rate. This rate which represents a certain amount of compensation that is due to people who give up some of their current consumption to save and to invest in bonds for the entrepreneurs to loan from.

Other events being equal, savers are likely to save more at higher rates of interest and entrepreneurs would desire to borrow at lower rates of interest. The individuals that oversee finances investigate this market frequently to understand the possibility of substitutions among the savings instruments. This frequent review is necessary for achieving a more diversified portfolio, compelling asset substitutability, and overall speculative advantages for maximizing the earnings from the portfolio of the savings' instruments. Also, entrepreneurs review the condition of the interest rate frequently to have an opportunity for loaning money to lower their cost of operations. 
Entrepreneurs could focus their attention at international instead of at domestic borrowing to fund their operations of housing if this insight is deemed profitable. Borrowing international funds would lead to the decrease of the demand for the domestic funds and as a result the domestic interest rate would be dragged down. This situation would present a golden opportunity for the entrepreneurs to exogenously increase the domestic demand for the loanable funds at the adjusted favorable rates. Using more equity than bonds in the business operations would tend to decrease the demand for bonds and their rates would therefore decline. Given the depressed bonds market, the entrepreneurs could exogenously increase the quantity of bonds demanded at favorable rates. If labor is used as a substitute for capital, by withholding borrowing for more capital acquisition, the interest rates would be depressed. At the depressed rates, the entrepreneurs would have the favorable advantages to expand the borrowing for capital expansion to enhance profitability.

Entrepreneurs could even delay their operations on foreclosed housing to take advantage of a decrease in the rates on bonds that provide operating finances. Bonds sellers may even accept lower rates whereby the housing agencies, buyers of the bonds have an established prudence in declaring and paying out interest when due. With the trustworthiness of paying out the interest when due, the entrepreneurs could have the leverage for achieving much lower rates than the market would have settled given limited trustworthiness. Lowered rates of borrowing could be the starting point for maximizing profit.

Policy events at the Fed could be used by entrepreneurs to improve their profit condition. If they have the foresight that the Fed would be increasing the discount rate that influences other interest rates, the entrepreneurs could choose to purchase more bonds at the prevailing rates before the Fed's discount rate announcement is implemented. With the expectation of rate decrease in the near future, the market entrepreneurs would buy less bonds at the ongoing rates. Understanding of and relating to the activities at the Fed are some other market attributes for improving profitability. Recall that the interest rate has been close to zero during and after the recent recession. The low rate may have provided the entrepreneurs with the opportunity to have access to cheap loans.

\section{Data, Methodology, and Results}

The data for this study is retrieved from various sources (Note 3). The foreclosure fillings variable is the yearly number of the foreclosures filled. While the completed foreclosures variable represents the yearly number of the foreclosures filled that passed through the phases of the foreclosure process, the homes repossessed variable is the yearly number of homes repossessed. For analytical purpose, the series are transformed into percentage change to be accommodated in the graph on one dimensional plane. Also, the interest rate series is the yearly rate of the $A A A$ rate, the wage index is the national average wage index, and the price of housing is the indexed average of the Consumer Price Index (CPI). How much that each of these variables relates to the indexed price of housing could determine the level of the windfall profit.

Generally, the nominal $A A A$ interest rate has been very close to zero and therefore there was no inflationary pressure during the period. The following Table 1 provides the basic descriptive statistics on foreclosure fillings, completed foreclosures, home repossessed, interest rate, and the indexed price of housing. The estimates of the price of the housing and of the interest rate are very less stochastic than the estimates of the other variables. The relative stability of the price of the housing in the presence of the high variation of the respective series provide yet additional proof that the recession provided an opportunity for the windfall profit.

Table 1. Averages and standard deviation of the series

\begin{tabular}{lll}
\hline Series & Average & Standard Deviation \\
\hline Foreclosures Fillings & 2653902 & 1078223 \\
\hline Completed Foreclosures & 2150805 & 1151683 \\
\hline Homes Repossessed & 734397.1 & 309642.9 \\
\hline$A A A$ rate & 4.94125 & 1.005477 \\
\hline Wage Index & 42849.61 & 2195.831 \\
\hline Housing CPI & 102 & 3.86 \\
\hline
\end{tabular}


Methodologically, the entrepreneurial objective, windfall in the depressed housing market can be stated as a linear function of the indexed price of housing $(H C P I)$ as:

$$
\text { Windfall }=\mathrm{f}(H C P I) \text {. }
$$

Other things remaining equal, a positive relationship is assumed between the indexed price of housing that reflects the related opportunity costs, and the windfall profit. A rapidly increasing HCPI could lead to an exponential growth of the windfall and a gradual increase of the HCPI would lead to a moderate enhancement of the windfall. In figure 1, the foreclosure fillings (Forec) has a very rapidly increasing trend up to 2007 in the presence of a slight decreasing trend of the indexed price of housing. The foreclosure fillings seemed to have caused a panic that depressed the demand for housing and the indexed price of housing deceased as a result.

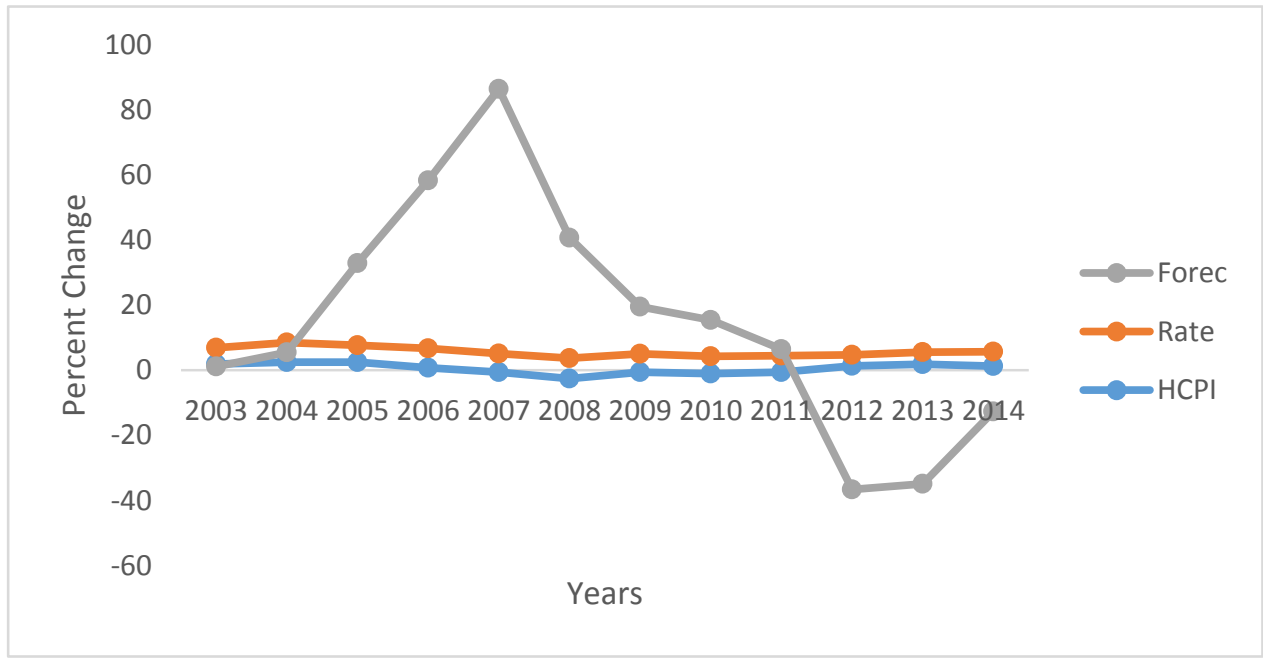

Figure 1. Time series of \% change in in housing CPI, interest rate, and foreclosure fillings

As from 2007, a very rapidly decreasing trend of the foreclosure fillings variable is present up to 2009 and thereafter it decreases gradually until 2011 and then it decreases very rapidly until 2012. As from 2012, it has a rapidly increasing trend up to 2014 that could reflect a reducing consumer market confidence during the period. As from 2009, the indexed price of housing maintained a slight increase in the presence of the declining foreclosure fillings. As explained in Ellen et al. (2012) the increasing indexed price of housing could be reflecting both the impacts of the decrease in the production of housing and a gradual return of market confidence in the recovering housing market. A return of market confidence is implied by the slightly increasing indexed price of housing between 2012 and 2014 even though the foreclosure fillings variable has a sharp increasing trend.

Since the interest rate is relatively low and stable, the increasing indexed price of housing in Figure 1 would not be reflecting inflationary pressure due to an increasing quantity of short term money. Rather it appears to be reflecting the impact of the negative shock on the production of the housing. During the period studied, the interest rate points in Figure 1 were statistically very low and similar except in 2008 when it experienced a very small decline. The rate has to be substantially reduced to have an expansionary short term quantity of money to initiate inflationary pressure on the indexed price of the housing. Therefore, with the relative stability of the interest rate, the increasing indexed price of housing of the period is basically reflecting the impact from the shock on the production of housing, from the enhanced market confidence, and not from an inflationary pressure. With an increase in the level of the foreclosure disturbances, the indexed price of housing would firstly decline due to the fallen housing demand, and as the production of the housing decreased and market improved, opportunities were provided for the indexed price of the housing to increase.

The relationship between the housing indexed price and the various levels of foreclosures-foreclosure fillings (Forec), completed foreclosures (Compf), and home repossessions (Hrepo) can be ascertained from figure 2 that also includes the interest rate factor. 


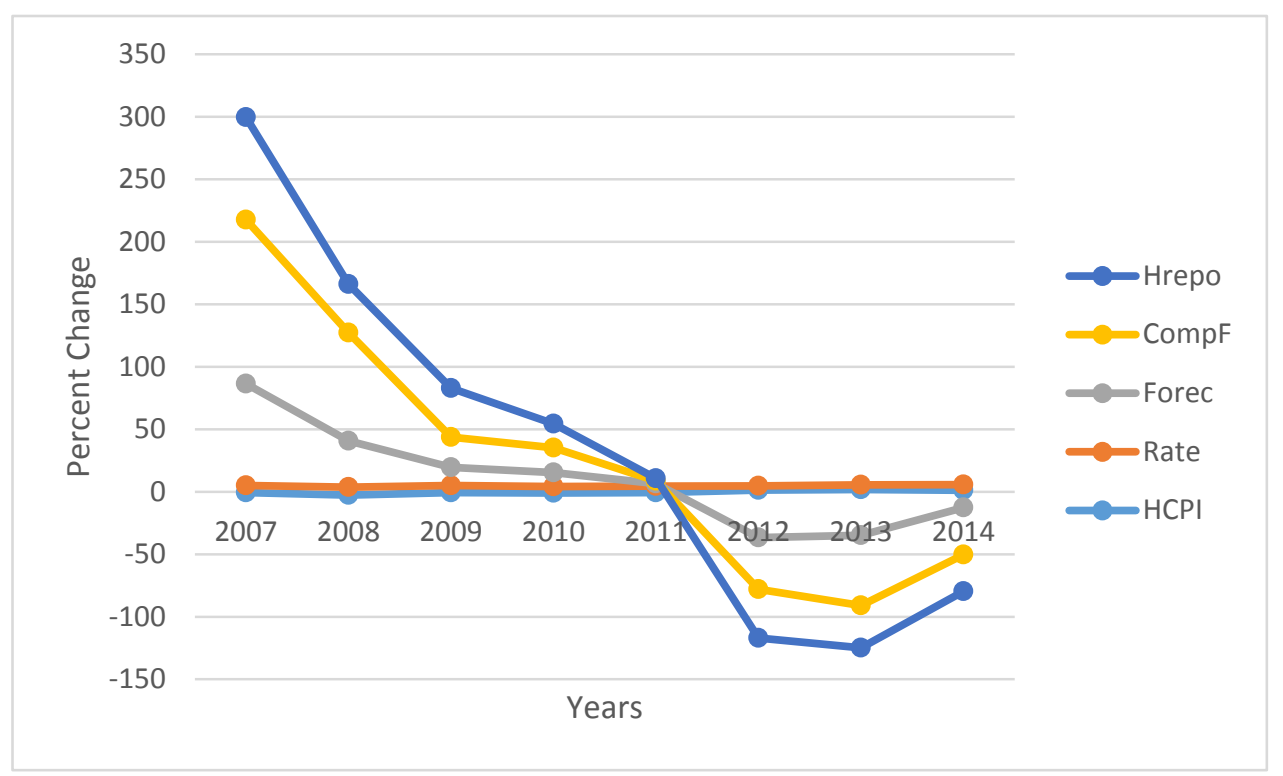

Figure 2. Time series of $\%$ change housing CPI, interest rate, foreclosure fillings, completed forclosures, and home ropossessions

In the presence of a limited change in the low interest rate, the different levels of the foreclosures decrease and the housing indexed price trend increased slightly and generally; thus giving rise to the windfall profit. From 2007 and up to around 2012, the different levels of the foreclosures had declining trends and observed increasing trends thereafter. It could therefore be stated categorically that the final outcome from the depressed housing demand and the decreased housing production and from the market improvement is an increase in the indexed price of the housing. In a nutshell, with the depressed indexed price of housing due to the fallen demand and with the reduced production of the housing, the indexed price of the housing that reflects all the opportunity costs of housing tended to increase. The increase in the indexed price of housing would stand to explain the windfall profits of the housing innovative entrepreneurs.

\section{Conclusion and Future Study}

Market entrepreneurs apply to compelling opportunities to realize economic windfall. They seemed to have profited from the massive housing foreclosures during the Great Recession. By refinancing and repurchasing the profitable quantities at the favorable lowest cost and distributing them at the highest possible prices driven by the fluctuation of the housing demand, decreased housing production, and market recovery, the entrepreneurs seemed to have realized some windfall. Particularly, the realization of the windfall seemed feasible given the market failure and later recovery, and the entrepreneurial arbitrage led to the acquisition and distribution of the properties at favorable terms. With the profit earning behavior, they would maximize profit from the randomized distributed opportunities in the conditions of either booms or busts and given the concentration of firms in the market.

Also, Americans have the desire to fulfill their American dreams. A normal good like housing seems to be the most preferable item for fulfilling the dreams. The desires to fulfill the dreams could lead to both conspicuous consumption and overconsumption of housing especially at substantially reduced interest rates and at various levels of incomes. A reduced growth rate of the average income in the 2000s gave rise to the housing market failure and the inability to continue payments on the housing consumption. In the 1990s the average income sustained some reasonable growth due to the opportunity and receipts provided by the then expanding Information Technology market. Given the expanding average income of the 1990s and without the due regards to income constraints, the real property consumers, at subprime interest rates, acquired very expensive houses. The 2000s' market failure due to the declining growth of the average income tended to have provided the opportunities for realizing the entrepreneurial windfall.

In a nutshell, the 1990s growth rate of the average income fell in the 2000s and as a result there was a default of payments on the conspicuous consumption and on the overconsumption of the housing properties. Therefore, the demand for housing declined and its price was depressed as the quantity produced of housing exceeded the quantity 
demanded of housing. With the market failure, the foreclosure fillings, the completed foreclosures, the home repossessions, the adjusting quantity of housing, and very low mortgage rates characterized the period.

Entrepreneurs as profit maximizers seemed to have refinanced or acquired inventories of the foreclosed properties at reasonably favorable terms. With a market recovery, the foreclosures filled, the completed foreclosures, and the homes repossession decreased while the price of the housing that reflects the related housing opportunity cost increased. With the improved price of the housing, the entrepreneurs are provided with the opportunity to achieve the housing market windfall. Studies on economic windfall are not common. Therefore, future studies on the topic could focus on comparative studies to quantify the windfall situations from various levels of market concentrations. Particularly, these kinds of studies would highlight the magnitudes of the windfall most especially in economic recessionary periods.

\section{References}

Arrow, K. J. (1985). The theory of discrimination. Applied Economics, 6.

Ashenfelter, O. (1978). Estimating the effect of training program on earnings. Review of Economics and Statistics, 60(1), 47-57. https://doi.org/10.2307/1924332

Ellen, I. G., \& Dastrup, S. (2012). Housing and the Great Recession. The Russell Sage Foundation and the Stanford Center on Poverty and Inequality.

Rich, R. (2013). The Great Recession, December 2007-2009. Federal Reserve History, Federal Reserve Bank, New York.

Rosenzweig, M. R. (1990). Population growth and human capital investments: Theory and Evidence. Journal of Political Economy, 98(5), 38-65. https://doi.org/10.1086/261724

Schumpeter, J. A. (1989). Essays: On entrepreneurs, innovations, business cycles, and the evolution of capitalism. Transaction Publishers.

Scopelliti, D. M. (2014). Housing: Before, During, and After the Great Recession. U.S. Bureau of Labor Statistics. Spotlight on Statistics (pp. 1-25).

Ucbasaran, D., Westhead, P., \& Wright, W., (2007). Opportunity identification and pursuit: Does an entrepreneur's human capital matter?. Small Business Economics, 30, 153-173. https://doi.org/10.1007/s11187-006-9020-3

\section{Websites}

https://www.ssa.gov/OACT/COLA/AWI.HTM1

https://www.federalreservehistory.org/essays/great_recession_of_200709

http://www.statisticbrain.com/home-foreclosure-statistics/

http://research.stlouisfed.org/fred2/series/AAA

http://www.globalpropertyguide.com/real-estate-housing-prices/U.

\section{Notes}

Note 1. See the trend of the National Average Wage Index at https://www.ssa.gov/OACT/COLA/AWI.HTM1

Note 2. Retrieved from: https://www.federalreservehistory.org/essays/great_recession_of_200709

Note 3. Foreclosures data comes from http://www.statisticbrain.com/home-foreclosure-statistics/ while the Aaa Bonds rate is retrieved from http://research.stlouisfed.org/fred2/series/AAA The Hosing Consumer Price Index is retrieved from http://fred.stlouisfed.org/series/USACPIHOUM 